\title{
The Interrelation Among Course Mastery, Technology Integration Self Efficacy, and Technological Pedagogical Content Knowledge (TPACK) of Prospective Science Teachers
}

\author{
Iana Zahwa ${ }^{\bowtie}$, Sigit Saptono, Pramesti Dewi \\ Pascasarjana, Universitas Negeri Semarang, Indonesia
}

\begin{tabular}{|c|c|}
\hline Article Info & Abstract \\
\hline $\begin{array}{l}\text { Article History : } \\
\text { Received June } 2020 \\
\text { Accepted July } 2020 \\
\text { Published April } 2021\end{array}$ & \multirow{3}{*}{$\begin{array}{l}\text { Technological Pedagogical Content Knowledge (TPACK) is an important } \\
\text { competency that must be had by prospective teachers to realize } 21^{\text {st }} \text {-century } \\
\text { learning. This research was aimed to analyze the relationship and the effect of } \\
\text { course mastery and Technology Integration Self Efficacy (TISE) on TPACK of } \\
\text { the prospective science teachers. This research was correlation research. By } \\
\text { using regression analysis, the relationship between course mastery and TISE } \\
\text { was analyzed on the TPACK of the science teacher candidates. Based on the } \\
\text { analysis, it was known that the average of course mastery, TISE, and TPACK } \\
\text { of prospective science teachers is good enough. Meanwhile, multiple regression } \\
\text { tests were related to the relationship between course mastery and Technology } \\
\text { Integration Self Efficacy (TISE) on TPACK of science teacher candidates } \\
\text { simultaneously showed a strong correlation with the correlation coefficient (R) } \\
\text { of } 0.736 \text { and R square of } 0.542 \text {. It means there is an effect of course mastery } \\
\text { and TISE on the TPACK of the prospective science teacher by } 54.20 \% \text {. }\end{array}$} \\
\hline $\begin{array}{l}\text { Keywords: } \\
\text { Course Mastery; Technol- } \\
\text { ogy Integration Self } \\
\text { Efficacy; Technological } \\
\text { Pedagogical Content } \\
\text { Knowledge }\end{array}$ & \\
\hline & \\
\hline
\end{tabular}

\footnotetext{
$凶$ correspondence:

Pascasarjana, Universitas Negeri Semarang, Indonesia

p-ISSN 2252-6412

Jalan Kelud Utara III Kota Semarang, Jawa Tengah, Indonesia 50237

e-ISSN 2502-4523

E-mail: Iyana.jahwa23@gmail.com
} 


\section{INTRODUCTION}

Technological Pedagogical and Content Knowledge (TPACK) is the meeting point where technology (computer, video, visuals), pedagogy (teaching methods, learning model), and content (such as science, geography, and mathematics) are used together (Graham, 2011). In other words, Technological Pedagogical and Content Knowledge (TPACK) is a competency where technological information, pedagogy, and learning content meet. Nowadays, Technological Pedagogical and Content Knowledge (TPACK) has been developed for $21^{\text {st }}$ century skills and has become a framework for developing teacher and prospective teacher's readiness in dealing with $21^{\text {st }}$-century skills (Figg \& Jaipal, 2012).

Technological Pedagogical and Content Knowledge (TPACK) involves several things, including 1) presents the concept of using technology; 2) utilize technology in teaching knowledge content through pedagogical methods and techniques; 3) identify what makes learning concepts considered easy or difficult and determine how to utilize technology to solve problems faced by students; and 4) decide how to use technology to teach students new knowledge or strengthen their knowledge (Koehler, 2006).

The use of ICT in the classroom is essential to allow students to learn and apply the 21st-century skills needed. $21^{\text {st-century skills that students need }}$ are collaboration, communication, ICT literacy, social or cultural competence, creativity, critical thinking, and problem-solving. Therefore, ICT is considered as a link for students to acquire $21^{\text {st }}$ century skills (Ratheeswari, 2018; Valtonen et al., 2017). However, meaningful integration of technology in learning is not easy, especially for prospective science teachers. Prospective science teachers must master the material to be taught to choose the right technology so that they can analyze the character of the material (Srisawasdi, 2012). Prospective teachers should have mastery of knowledge and teaching skills as a provision to improve the abilities that have been given during the lecture process in the educational institutions, they have participated in.

Teacher education is designed to equip the knowledge, skills, and attitudes that teacher candidates need to teach in class. In general, teachers have expertise derived from a combination of pedagogical, content, knowledge about students, and environmental contexts. According to Tantrarungroj (2012), TPACK is used to represent teachers' expertise in integrating technology in learning. It is a form of knowledge needed for the smart use of technology in teaching and learning. In TPACK, knowledge, and the ability to integrate technology on learning will make learning more effective and efficient (Oyanagi \& Satake, 2016).

Prospective teachers have low TPACK capabilities. They need improvement. It can be seen from previous studies related to TPACK prospective teachers' ability, Lestari (2015) concluded that TPACK's planning and implementation capabilities were only limited to the use of infocus and whiteboards that were implemented in group presentation activities. Sukaesih's et al. (2017) research showed that teacher candidates' TPACK ability still needs to be improved in several aspects such as content, pedagogy, and technology. Another research by Nurdiana (2014) revealed, TPACK ability of prospective teachers is still low and cannot integrate technology in learning yet.

The data shows that TPACK is still low and naturally raises questions about things that can affect the ability of TPACK itself. Is the mastery of educational courses strongly related to the TPACK ability of prospective teachers? Or there are other more influential factors such as Technology Integration Self Efficacy (TISE), which has been considered to affect the ability of TPACK. Technology Integration Self Efficacy (TISE) is a teacher's confidence or confidence in integrating technology into learning. Ertmer, P. A \& Ottenbreit-Leftwich (2010) emphasized that it is not enough if teachers do not have self-efficacy to use ICT knowledge and teaching skills. The attitude and confidence of prospective teachers is the most significant factor that can affect TPACK. Anxiety and low confidence in prospective teachers can be a severe disadvantage for prospective teachers to integrate technology into learning. TISE is considered the best predictor of teachers' intention to use technology in their classrooms (Anderson et al., 2011). Koçak-Usluel et al. (2015) added that integration is affected by several elements: beliefs, self-regulation, motivation, and interaction between these elements.

The purpose of this study was to determine the relationship between course mastery and 
Technology Integration Self Efficacy (TISE) on Technological Pedagogical and Content Knowledge (TPACK) of prospective science teachers and analyze the effect of course mastery variables and Technology Integration Self Efficacy (TISE) on Technological Pedagogical and Content Knowledge (TPACK) of prospective science teachers.

\section{METHOD}

This research was a correlational study, which was conducted at a private university in Central Java. The research subjects were 27 students of the Faculty of Teacher Training and Education, Science Education Study Program, sixth semester who were taking the microteaching course.

Data collection methods were questionnaires, tests, observations through learning videos, lesson plans analysis, and documentation. The questionnaire method was used to obtain TISE and TPACK data for prospective science teachers. The questionnaire used was a TPACK questionnaire adapted from Mishra \& Koehler (2006) and the TISE questionnaire adapted from Wang (2004). The test method was used to obtain data from course mastery. The observation method was carried out to determine the ability of prospective teachers in teaching practice. However, in this study, observations were made by analyzing instructional videos made by prospective teachers because they could not carry out practical teaching activities directly due to the Covid-19 pandemic. Meanwhile, the documentation method was used to collect data related to research.

The research data collected was then analyzed using descriptive statistics, regression equation tests, simultaneous tests, and coefficient of determination.

\section{RESULT AND DISCUSSION}

\section{Product Moment Correlation Analysis}

The relationship between independent variables (course mastery, and Technology Integration Self Efficacy (TISE)) and the dependent variable (Technological Pedagogical Content Knowledge (TPACK)) was calculated by using the product-moment correlation analysis with SPSS 21.00. The following results are obtained:
Table 1. Results of Product Moment Correlation Analysis

\begin{tabular}{lll}
\hline Variable & $\mathrm{R}$ & Sig \\
\hline Courses & 0.242 & 0.224 \\
TISE & 0.736 & 0.000 \\
\hline
\end{tabular}

The first test result is the relationship between course mastery and Technological Pedagogical Content Knowledge (TPACK). Pearson correlation value obtained is 0.242 with $p$-value (sig) of 0.224 . Pvalue $>0.05$ indicates a non-significant positive relationship between the course mastery and the Technological Pedagogical Content Knowledge (TPACK) of the prospective science teachers. The second test result is the relationship between Technology Integration Self Efficacy (TISE) with Technological Pedagogical Content Knowledge (TPACK). It is obtained a Pearson correlation value of 0.736 with a p-value (sig) of 0.000 . P-value $<0.05$ indicates that there is a positive and significant relationship between Technology Integration Self Efficacy (TISE) and Technological Pedagogical Content Knowledge (TPACK). The higher the TISE score, the higher the TPACK will be had by the prospective science teachers or vice versa. The lower the TISE score, the lower the TPACK of the prospective science teachers.

\section{Multiple Correlation Analysis}

Hypothesis testing regarding the relationship between subject mastery and Technology Integration Self Efficacy (TISE) with Technological Pedagogical Content Knowledge (TPACK) used multiple correlation tests. The results of the multiple correlation tests between the course mastery and Technology Integration Self Efficacy (TISE) with Technological Pedagogical Content Knowledge (TPACK) obtained a value of 0.736 with a $p$-value (sig) of 0,000 . P-value $<0.05$ indicates that there is a positive and significant relationship between course mastery and Technology Integration Self Efficacy (TISE) simultaneously with Technological Pedagogical Content Knowledge (TPACK).

\section{Multiple Linear Regression Analysis}

Based on the results of multiple linear regression calculations, the following regression equation is obtained:

$$
\begin{aligned}
& Y=a+b 1 X 1+b 2 X 2 \\
& Y=90,140+0,012 X+1,380 X
\end{aligned}
$$


As seen from the regression equation and correlation graph above, it is known that the value of the regression coefficient of course mastery (X1) is 0.012 with a positive sign, which means that if mastery of the course increases by 1 unit, the TPACK of the teachers' candidate will increase by 0.012 . However, the value of sig.> 0.05 means course mastery does not significantly affect the TPACK of prospective science teachers.

The TISE regression coefficient (X2) was 1.380 with a positive sign. If the TISE value increases by 1 unit, the TPACK of teacher candidates will increase by 1.380 .

\section{Simultaneous Test (F Test)}

Simultaneous test results between course mastery and Technology Integration Self Efficacy (TISE) simultaneously with Technological Pedagogical Content Knowledge (TPACK) can be seen in Table 2 below:

Table 2. Simultaneous Test Results

\begin{tabular}{lll}
\hline Variable & F & Sig \\
\hline
\end{tabular}

Course Mastery, TISE $14.584 \quad 0.000$

Based on the results of simultaneous tests, the $\mathrm{F}$ value of 14.584 ( $>\mathrm{F}$ table 8.38) with a p-value (sig) of 0.000 . P-value $<0.05$, the linear regression obtained can be used to make conclusions about the relationship between some variables being studied. In other words, there is an effect between the course mastery and TISE on the TPACK of the prospective science teachers.

\section{Determination Analysis Test}

Determination analysis was used to determine the percentage of the effect of the independent variable $(\mathrm{X} 1, \mathrm{X} 2)$ on the dependent variable $(\mathrm{Y})$. The results of the determination analysis can be seen in the following table 3 :

Table 3. Results of the Determination Analysis

\begin{tabular}{llll}
\hline Variables & R & R square & Sig. \\
\hline Course Mastery & 0.242 & 0.059 & 0.224 \\
TISE & 0.736 & 0.542 & 0.000 \\
Course Mastery, & 0.736 & 0.542 & 0.000 \\
TISE, TPACK & & &
\end{tabular}

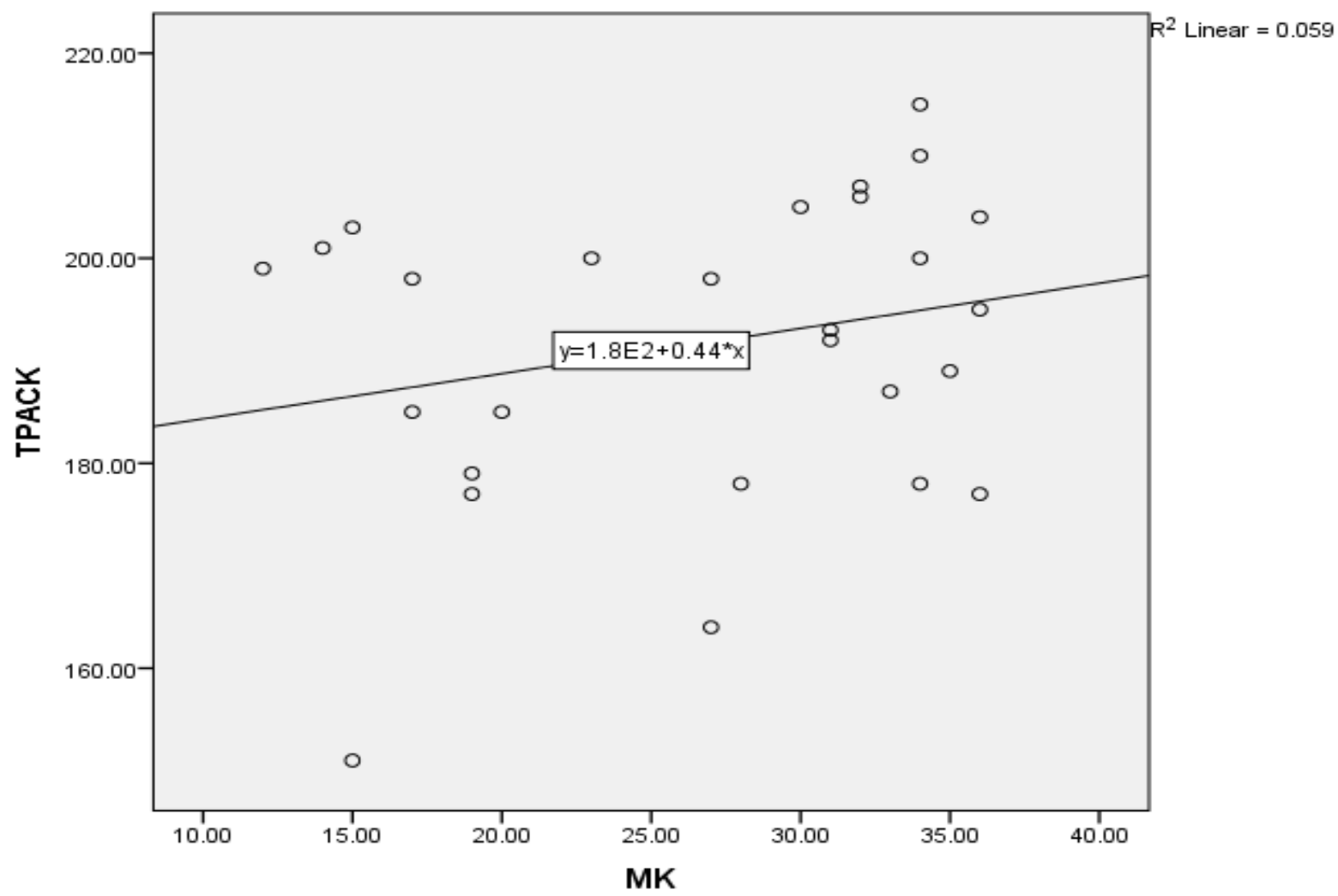

Figure 1. Correlation Graph Between Course Mastery and TPACK

Based on table 3 and correlation graph above, it can be seen that the value of $\mathrm{R}$ square (course mastery) is 0.059 or $5.9 \%$. It shows that the percentage of contribution of course mastery variables to TPACK of prospective teachers is $5.9 \%$ and $94.1 \%$ is affected by other variables not included 
in this study because the sig value $>0.05$, then the relationship that occurs is not tested significantly.

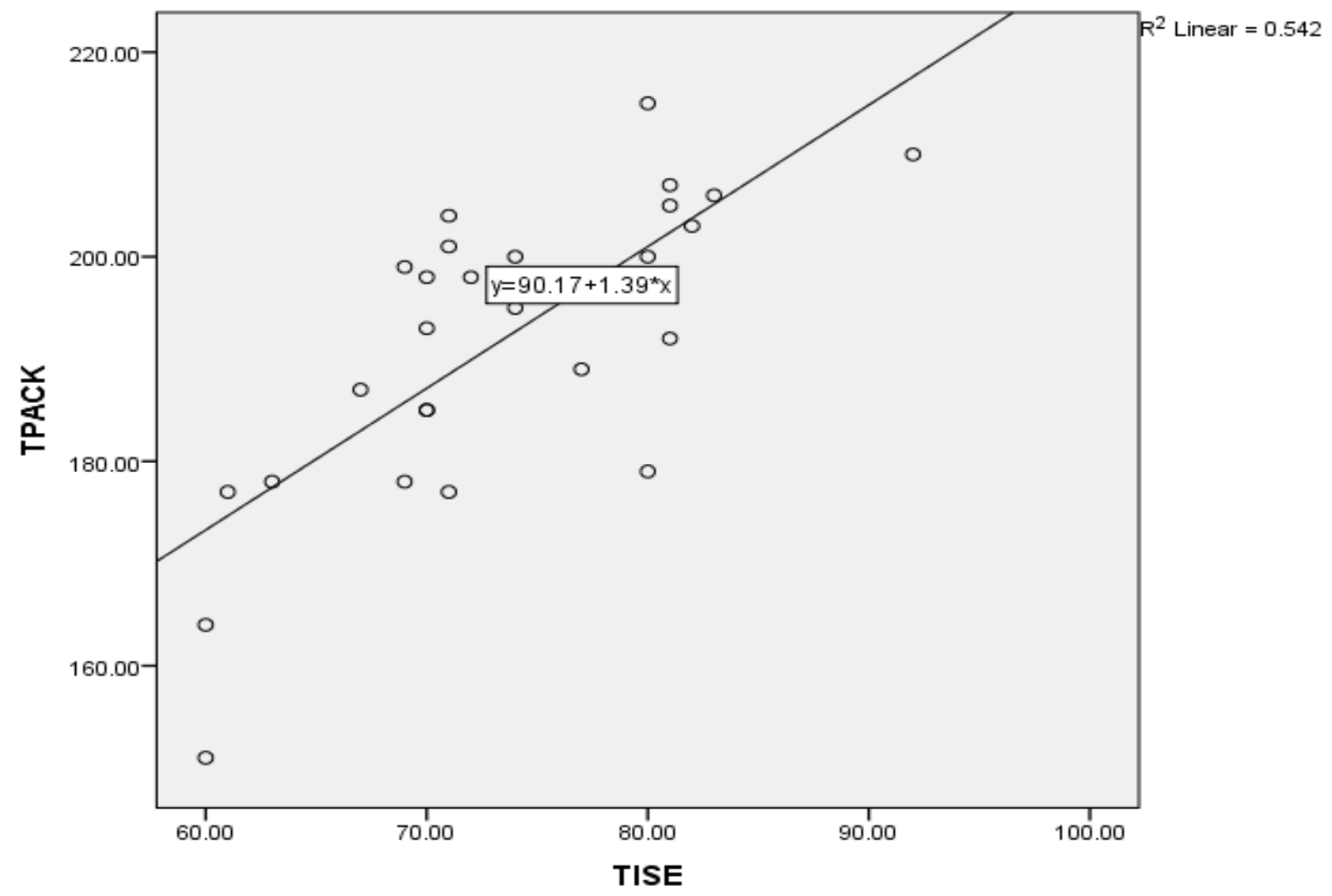

Figure 2. Correlation Graph Between TISE and TPACK

The value of $\mathrm{R}$ square (Technology Integration Self Efficacy (TISE)) is 0.542 or $54.2 \%$ with a p-value (sig) of 0.000 , thus $p$-value $<0.05$. It shows that TISE significantly contributed to TPACK by $54.2 \%$ and $45.8 \%$ is affected by other variables not included in this study.

In general, self-efficacy is a person's belief in his ability to organize and carry out the actions needed to produce the desired achievement. Bandura's Theory (1997) in Topkaya (2010) explained that selfefficacy influences various aspects, such as behavior, actions, amount and duration of effort done by someone, and emotional responses to the success of something. High self-efficacy is expected to provide positive support in taking action.

In terms of technology in teaching and learning, self-efficacy is considered to play a role in teachers' thoughts and actions using technology $\mathrm{n}$ in the classroom. Then, self-efficacy is self-confidence in the ability of prospective teachers to integrate technology in the classroom or commonly referred to as Technology Integration Self Efficacy (TISE). It is in line with the research result that shows, Technology Integration Self Efficacy (TISE) had a significant effect on Technological Pedagogical and Content Knowledge (TPACK) of prospective teachers, which is $54.2 \%$.

The results of these studies are strengthened with previous studies that show significant results as well. Abbitt (2011), which stated that there is a relationship between Technology Integration Self Efficacy (TISE) with each subscale of Technological Pedagogical and Content Knowledge (TPACK), which is positively correlated and quite strong $(r=0.853 ; p$ $<0,01)$.

The other research by Keser et al. (2015) shows that the correlation analysis results between TISE and TPACK perceptions are high, positively correlated with moderate correlation levels, and significant between the two variables. The research also mentioned that TISE of teacher candidates are essential predictors of TPACK. The next research is Qudsiya et al. (2018), which showed the relationship between TISE and TPACK by $37.30 \%$.

TISE is considered the best predictor of teachers' intention to use technology in their classrooms (Anderson et al., 2011). Koçak-Usluel et al. (2015) added that integration is influenced by several elements: beliefs, self-regulation, motivation, 
and interaction between these elements. According to a study conducted by Ertmer \& OttenbreitLeftwich (2010), negative perceptions of technology integration become the biggest obstacle in technology integration. It is followed by inadequate technological support as the second-largest control. The solution to improve TISE is through training, where teachers are accustomed to facing technology. Thus, TISE can improve.

Table 3 it is known the relationship and contribution of course mastery and TISE simultaneously to the TPACK of the prospective science teachers. Based on multiple regression analysis, $\mathrm{R}$ square values of 0.542 or $54.20 \%$ were obtained. It shows that the effect of the course mastery and TISE together on TPACK has the same effect as TISE on TPACK. In other words, the course mastery does not directly affect the TPACK of prospective teachers, and the level of TPACK of prospective teacher-students is more affected by TISE. In line with Pajares (1992) in Abbitt (2011), knowledge and confidence are the main factors in planning, choosing, and making decisions regarding actions. However, it is not enough to rely solely on knowledge, teachers or prospective teachers must have the confidence in using the knowledge and skills they have to facilitate learning (Ertmer \& Ottenbreit-Leftwich, 2010)

The explanation above is in accordance with the results of research that shows, course mastery has an insignificant effect on TPACK if it stands alone. Meanwhile, TISE has a quite strong relationship and affect on TPACK, which is $54.2 \%$. Furthermore, knowledge (course mastery) and TISE together can affect TPACK by $54.2 \%$. It shows that to have a good TPACK competency. Prospective teachers are not enough if they only mastery the course, but must be supported by other factors such as self-confidence in integrating technology in learning. Moreover, course mastery does not affect the TPACK of prospective teachers. It is evidenced by the value of the effect between course mastery and TISE on TPACK is equal to TISE's effect with TPACK, which is $54.2 \%$.

These results are supported by interview data with prospective teachers conducted over the telephone network. The interview results showed that the prospective teacher felt lack just by having the knowledge they had gained through the course. According to prospective teachers, having a good course score may not necessarily be a professional teacher. To be a professional teacher and have the ability to integrate technology in learning requires other supporting factors, and one that is important is confidence

Based on the results of the interview, it can be seen that the knowledge that prospective teachers get through the courses is considered insufficient to have a good level of TPACK competence, but the knowledge gained can help them as prospective teachers in preparing lesson plans. The ability of prospective science teachers to prepare lesson plans and integrate technology can be seen from the analysis of the lesson plans and learning videos:

Table 4. Lesson Plan Analysis Results

\begin{tabular}{lll}
\hline Category & $\mathrm{N}$ & Percentage (\%) \\
\hline Very good & 9 & 33.3 \\
Good & 14 & 52 \\
Enough & 1 & 3.7 \\
Poor & 3 & 11 \\
\hline
\end{tabular}

Table 5. Results of Analysis of Learning Videos

\begin{tabular}{lll}
\hline Category & $\mathrm{N}$ & Percentage (\%) \\
\hline Very Good & 4 & 15 \\
Good & 15 & 55 \\
Enough & 8 & 30 \\
Poor & 0 & 0 \\
Very Poor & 0 & 0 \\
\hline
\end{tabular}

Based on the results of the study (Table 4), it is known that as many as $52.00 \%$ of prospective teachers have good abilities in preparing lesson plans. Prospective science teachers already know the components and sequences in preparing lesson plans and adjust learning methods, instructional media, and assessments in accordance with teaching material in the lesson plans prepared. Meanwhile, the results of the video analysis in table 5 show, as many as $55 \%$ of prospective science teachers can make a good enough learning video. Prospective teachers have been able to carry out preliminary teaching activities accompanied by apperception; some have integrated technology in teaching in videos, animations, props, and power points. The media used are certainly very influential in the process of delivering subject matter to make it more effective, engaging, and understandable by students. The making of this learning video is intended as a substitute for direct teaching practice (microteaching), which cannot be implemented because of the Covid19 pandemic. Although through video learning, but 
the ability of prospective teachers to teach can be seen from the sequence of delivery of material. Starting with preliminary activities, core activities, closing and integrating technology in the teaching. Also, with the creation of instructional videos, prospective teachers are trained to create technologybased learning media. The learning video can fulfill two functions of learning media: a medium of learning in the classroom and a source of independent learning for students whenever and wherever they are (Fry et al., 2009). The results of the video analysis of learning can also be seen in the extent of the knowledge of prospective teachers related to learning methods, learning media, and content knowledge.

Based on the results of statistical analysis tests and interviews, it can be concluded that course mastery has a contribution to enrich the knowledge of prospective teachers about learning in school, as well as helping prospective teachers to have the ability to compile a learning media. The courses obtained also provide knowledge related to various learning models and media that can be applied to learning. However, course mastery (test scores) does not significantly affect the TPACK of prospective teachers. TPACK is a competency that consists of content and pedagogical knowledge and a combination of content, pedagogy, technology, and the ability to integrate all of these aspects in learning. TPACK is described as a form of multi-integration between content, pedagogy, and technology that is needed to equip student teacher candidates to provide a useful learning experience for students. (Hollan \& Piper, 2016; Sahin et al., 2013). Having this ability is not enough just with knowledge, other aspects affect, namely belief or confidence about the ability to facilitate student learning (Ertmer \& Ottenbreit-Leftwich, 2010).

\section{CONCLUSION}

Technological Pedagogical Content Knowledge (TPACK) is an important competency that must be possessed by prospective teachers. Several aspects can affect the Technological Pedagogical Content Knowledge (TPACK) of prospective teachers. The results showed that there was no significant relationship between course mastery with Technological Pedagogical Content Knowledge (TPACK) for prospective teachers, with a contribution of $0.012(1.20 \%)$ and a p-value (sig) of 0.224 . P-value $>0.05$ shows that the relationship between course mastery and Technological Pedagogical Content Knowledge (TPACK) is not significant.

There is a strong and significant relationship between Technology Integration Self Efficacy (TISE) with Technological Pedagogical Content Knowledge (TPACK) with a Pearson correlation value of 0.736 and $\mathrm{R}$ square is 0.542 . It means Technology Integration Self Efficacy (TISE) contributes 54.20\% to the Technological Pedagogical Content Knowledge (TPACK) of science teacher candidates.

The results also showed that the relationship between course mastery and Technology Integration Self Efficacy (TISE) with Technological Pedagogical Content Knowledge (TPACK) of prospective science teachers had an $\mathrm{R}$ square value of 0.542 with a $\mathrm{p}$ value (sig) of $0,000(<0.05)$. It can be interpreted that course mastery and Technology Integration Self Efficacy (TISE) jointly can affect the Technological Pedagogical Content Knowledge (TPACK) of prospective science teachers by $54.20 \%$. However, course mastery does not increase the value of $\mathrm{R}$ square because the $\mathrm{R}$ square value is the same as the $\mathrm{R}$ square value on the effect of TISE on TPACK.

\section{REFERENCES}

Abbitt, J. T. (2011). An Investigation of the Relationship between Self-Efficacy Beliefs about Technology Integration and Technological Pedagogical Content Knowledge (TPACK) among Preservice Teachers. 27(4).

Anderson, S. E., Groulx, J. G., \& Maninger, R. M. (2011). Relationships among preservice teachers' technology-related abilities, beliefs, and intentions to use technology in their future classrooms. Research, Journal of Educational Computing, 45(3), 321

Ertmer, P. A., \& Ottenbreit-Leftwich, A. (2010). Teacher technology change: How knowledge, confidence, beliefs, and culture intersect. Journal of Research on Technology in Education, 42(3), 255

Figg, C., \& Jaipal, K. (2012). TPACK in-Practice: Developing 21st Century Teacher Knowledge. Texas: Research Gate.

Graham, C. R. (2011). Theoretical considerations for understanding technological pedagogical content knowledge (TPACK). Computers \& Education, 53(3).

Holland, D.D \& Pipper, R.T. (2016). A Technology Integration Education (TIE) Model for Millenial Preservice Teachers: Exploring the Canonical Correlations Relationships among Attitudes, 
Subjective Norms, Perceived Behavioral Controls, Motivation, Technological, Pedagogical and Content Knowledge Competencies. Journal of Research on Technology in Education, 48 (3), 212-226

Keser, H., Gizem, F., Y1lmaz, K., \& Y1lmaz, R. (2015). TPACK Competencies and Technology Integration SelfEfficacy. 14(4), 1193-1207.

Koçak-Usluel, Y., Özmen, B., \& Çelen, F. K. (2015). Integration of ICT in learning and teaching process and a critical overview of TPACK model. Theory and Practice, Education Technology, 5(1), 34-5.

Koehler, M. J. (2006). Technological Pedagogical Content Knowledge: A Framework for Teacher Knowledge. Teachers College Record, 6(108).

Lestari, S. (2015). Analisis Kemampuan Technological Pedagogical Content Knowledge (Tpack) Pada Guru Biologi Sma Dalam Materi Sistem Saraf. Seminar Nasional Xii Pendidikan Biologi Fkip Uns 2015.

Mishra, P. Dan M. J. Koehler. (2006). Technological Pedagogical Content Knowledge: A Framework for Teacher Knowledge. Teachers College Record. 6 (108), 1017-1054

Nurdiana, Urip. (2014). Pengaruh Pelatihan Technological Pedagogical Content Knowledge (Tpck) Melalui Jejaring Media Sosial Terhadap Kemampuan Tpck Guru Sekolah Dasar. Tesis. Bandung: Universitas Pendidikan Indonesia.

Oyanagi, W., \& Satake, Y. (2016). Capacity Building in Technological Pedagogical Content Knowledge for Preservice Teacher. International Journal for Educational Media and Technology, 10 (1), 33.

Qudsiya, R., Widiyaningrum, P., \& Setiati, N. (2018). The Relationship Between TISE and TPACK among Prospective Biology Teachers of UNNES. 7(3), 305311.
Ratheeswari, K. (2018). Information Communication Technology in Education. 3, 45-47.

Sahin, I, et al. (2013). Analysis of Relationships Between Technological Pedagogical Content Knowledge and Educational Internet Use. Journal of Digital Learning in Teacher Education, 29 (4), 110 - 117

Srisaswadi. N. (2012). The Role of TPACK in Physics Classroom: Case Study of Preservice Physics Teachers. Procedia Social and Behavioral Sciences

Sukaesih, S., Ridlo,S., Saptono, S. (2017). Analisis Kemampuan Technological Pedagogical and Content knowledge (Tpack) Calon Guru Pada Matakuliah Pp Bio. Prosiding Seminar Nasional Pendidikan Sains (Snps)

Tantrarungroj Pornsook, S. P. (2012). Enhancing Preservice Teacher's Self-efficacy and Technological Pedagogical Content Knowledge in Designing Digital Media with Self-Regulated Learning Instructional Support in Online Project-Based Learning. Creative Education, 3(77).

Topkaya, E. Z. E. H. İ. R. (2010). Preservice English Language Teachers ' Perceptions of Computer SelfEfficacy and General Self-Efficacy. The Turkish Online Journal of Education Technology, 9(1), 143156.

Valtonen, T., Sointu, E., Kukkonen, J., Kontkanen, S., Lambert, M. C., \& Mäkitalo-siegl, K. (2017). TPACK updated to measure preservice teachers ' twentyfirst century skills. 33(3), 15-31.

Wang, L., Ertmer, P. A., Newby, T. J., Wang, L., Ertmer, P. A., Newby, T. J., Newby, T. J. (2004). Increasing Preservice Teachers' Self-Efficacy Beliefs for Technology Integration Increasing Preservice Teachers' Self-Efficacy Beliefs for Technology Integration. 1523. https://doi.org/10.1080/15391523.2004.1078241 4 